\title{
Impact of cadmium on the bacterial communities in the gut of Metaphire posthuma
}

\author{
Shih-Hsiung Liang a, ${ }^{\mathrm{a}}$, Mu-Hsuan Chen ${ }^{\mathrm{a}, 1}$, Chien-Cheng Chen ${ }^{\mathrm{a}}$, Colin S. Chen ${ }^{\mathrm{a}}$, \\ Jiun-Hong Chen ${ }^{\mathrm{b}}$, Ssu Ching Chen ${ }^{\mathrm{a}, *}$
}

a Department of Biotechnology, National Kaohsiung Normal University, Kaohsiung, Taiwan, ROC

b Department of Life Science, National Taiwan University, Taipei, Taiwan, ROC

\section{A R T I C L E I N F O}

\section{Article history:}

Received 26 April 2009

Received in revised form 2 July 2009

Accepted 29 July 2009

Available online 5 August 2009

\section{Keywords:}

Metaphire posthuma

Cadmium

DGGE

Bacterial community

\begin{abstract}
A B S T R A C T
The effects of cadmium (Cd) contamination in soil onto the bacterial communities of the guts pooled from ten Metaphire posthuma were addressed during 14 days' incubation. We found that about $50 \%$ of $\mathrm{Cd}(5 \mathrm{mg} / \mathrm{kg}$, dry weight soil) in the contaminated soil was bio-accumulated into the earthworms. DNA was extracted from the guts of $M$. posthuma and their dwelling soil irrespective of $\mathrm{Cd}$ treatment for the analysis of the bacterial communities of guts in M. posthuma and in soil by PCR-DGGE (polymerase chain reaction-denaturing gradient gel electrophoresis). A distinctive cluster of bacterial communities of the guts in the earthworm with and without Cd treatment using the analysis of unweighted pair-group method using arithmetic averages (UPGMA) was observed, indicating that the bacterial community of guts could be changed by $\mathrm{Cd}$. However, no differences in the bacterial communities in soil irrespective of $\mathrm{Cd}$ treatment were observed, which could be resulted from the bioremediation of $\mathrm{Cd}$ by earthworms leading to insignificant effect of $\mathrm{Cd}$ on bacterial communities in soil. For the sequencing of some of the dominant bands in the DGGE profile, Bradyrhizobium japonicum, Stenotrophomonas sp. D2, and Labrys, sp. CC-BB4, whose sequences display an identity of more than $97 \%$ using blast program against a known sequence in the GeneBank database and Ribosomal database, were identified.

Collectively, our results showed that earthworm treatment can decrease the concentrations of $\mathrm{Cd}$ in soil, and Cd cause a shift in the bacterial communities in the guts of M. posthuma. The application of $M$. posthuma for Cd bioremediation would be desired.
\end{abstract}

(c) 2009 Elsevier B.V. All rights reserved.

\section{Introduction}

The soil contamination with heavy metals is ubiquitous, presenting a possibly unacceptable risk to human and ecological health [1]. Earthworm as a common organism in soil is inevitably affected [2]. However, earthworms can survive in heavy metalcontaminated mine soil [3-5] with concentration of cadmium (Cd) exceeding $350 \mu \mathrm{g} / \mathrm{g}$ [6]. Indeed, cadmium can be accumulated in the earthworms inhabiting these metal-contaminated mine sites [7]. The ability of earthworms to live in the presence of toxic metals has promoted interest in their potential application as biomarkers for metals [7]. Therefore, many studies on the bioaccumulation of metals by earthworm have been extensively investigated mainly for the purpose of using earthworm as bioindicators of soil pollution or metal availability [8-12].

\footnotetext{
* Corresponding author. Fax: +886 76051353.

E-mail address: osycchna@ksts.seed.net.tw (S.C. Chen).

1 These authors contributed equally.
}

Studies of various earthworm species have generally shown that a large portion of the microbial population in soil passing through the gastrointestinal tract of the earthworm unchanged while representatives of some phyla increase in abundances [13]. The differences in microbial activity, bacterial numbers and certain bacterial species between the gut of earthworm or burrow and bulk soil suggested that the bacterial community structure of these habitats are different from those of the soil [13]. However, the structure and function of the bacterial community inhabiting the gut of earthworm is still poorly understood [14].

In this study, the exploration of bacterial community in gut of earthworms after Cd treatment was first performed using the denaturing gradient gel electrophoresis (DGGE) technique. DGGE is widely used to study the microbial composition of a variety of different habitats including the gut microflora of humans [15], pigs [16], wasps [17] or termites [18]. By DGGE, we herein presented evidences that only a shift of bacterial communities in the gut of earthworms but not in their dwelling soil with $\mathrm{Cd}$ treatment compared with their corresponding control groups (without $\mathrm{Cd}$ treatment) was observed. 


\section{Materials and methods}

\subsection{Earthworms treated with Cd}

The soil without Cd contamination was collected in a remote site in mountain area of Chang-Liou, Kaohsiung Country. Subsequently, the soil was homogenized by sieving through a $0.2-\mathrm{mm}$ mesh. This type of soil was stored at $4{ }^{\circ} \mathrm{C}$ for less than 3 days before the experiments were performed. The earthworm, Metaphire posthuma, was obtained from a local earthworm-breeding farm. For each of the three independent experiments, earthworms were maintained in three plastic containers ( $500 \mathrm{ml}$ ) filled with soil (dry weight, $200 \mathrm{~g}$; the contents of water, $40 \pm 5 \%$; the $\mathrm{pH}$ values, 7.0 ) for at least 3 -d acclimation before the determination of Cd concentration in earthworm or its dwelling soil. Theses containers were kept at $25^{\circ} \mathrm{C}$ and in the dark room for at least $24 \mathrm{~h}$. Adult M. posthuma with a welldeveloped clitellum and without Cd contamination were used for this study.

Three experimental settings (groups A, B and C) were performed. Soil containing ten earthworms without $\mathrm{Cd}$ treatment was designated as group A. Group B constituted only soil with Cd treatment ( $5 \mathrm{mg} / \mathrm{kg}$, dry weight basis). Group C was composed of ten earthworms and Cd-treated soil ( $5 \mathrm{mg} / \mathrm{kg}$, dry weight basis). The concentration level selected in this study referred to the maximum contaminant level (MCL) of Cd of $10 \mathrm{mg} / \mathrm{kg}$ in soil as regulated by Taiwan Environmental Protection Administration. The contents of water, the $\mathrm{pH}$ value, and $\mathrm{Cd}$ concentration in each group were determined in triplicate independently. The bacterial community between soil and the gut of earthworms was compared using DGGE analysis as described below.

\subsection{The determination of $C d$ concentration in earthworms or soil}

Ten earthworms were removed from groups $A$ and $C$, respectively, at sampling days $0,3,7,10$, and 14 during 14 -d incubation, and then were pooled to determine the level of $\mathrm{Cd}$ in the earthworm. Additionally, the residual $\mathrm{Cd}$ in soil in which the ten earthworms dwelled was tested. Determination of Cd concentration in earthworms or soil from groups $A$ and $C$ was performed by at least triplicate analyses.

Group A was served as the negative control because it contained no $\mathrm{Cd}$. For the digestion of soil and earthworm samples, $2 \mathrm{~g}$ of sample (wet weight) was transferred to a digestion vessel. Ten milliliters of concentrated hydrochloric acid was added to the sample. Subsequently, the sample was covered with a ribbed watch glass, and then was continued heating the digestate until the volume was reduced to approximately $5 \mathrm{ml}$. The digestate was filtered through Whatman No. 41 filter paper (or equivalent) before the collection of digestate in a $100 \mathrm{ml}$ volumetric flask. Finally, this sample was analyzed by flame atomic absorption spectrometry (FLAA). Before the analysis of Cd by FLAA, the standard stock solution was prepared. For this standard solution, $1.000 \mathrm{~g}$ of $\mathrm{Cd}$ was dissolved in $20 \mathrm{ml}$ of $1: 1 \mathrm{HNO}_{3}$, and then was diluted to 11 with reagent water. Thereafter, we prepared five concentration levels of standard solution for the determination of $\mathrm{Cd}$ concentration. The detection limit of Cd concentration was $0.005 \mathrm{mg} / \mathrm{l}$.

\subsection{DNA extraction and PCR amplification of target DNA}

Earthworms were sedated, surface sterilized with ethanol (70\%). Subsequently, the gut of the earthworms were depurated under sterile conditions. The whole gut content of each specimen was extracted with a small sterile spatula and directly transferred into sterile $1.5 \mathrm{ml}$ micro-centrifugation tube. Each gut sample was separately used for DNA extraction. DNA extraction from the ten of M. posthuma gut and their dwelling soil was performed using Soil
DNA extraction kit (GeneMark, Taiwan) according to the manufacture's protocol. Extracted DNA was amplified in a PCR thermocycle (Eppendorf, Germany) with a set of primer F968gc and R1401 as described [19]. Each PCR mixture contained 5-15 ng extracted DNA, $0.5 \mu \mathrm{M}$ of each primer, and $25 \mu$ l Master Mix RED (Ampliqon, Denmark) containing $0.4 \mathrm{mM}$ dNTP-Mix, $2.5 \mathrm{mM} \mathrm{MgCl}_{2}, 0.025 \mathrm{U} / \mu \mathrm{l}$ ampliqon taq DNA polymerase, and DNA polymerase buffer. For amplification of the bacterial $16 \mathrm{~S}$ rDNA primer F968gc-R1401, a touchdown-PCR program with an initial denaturation step at $94^{\circ} \mathrm{C}$ for $4 \mathrm{~min}$, followed by 5 thermal cycles of $1 \mathrm{~min}, 1 \mathrm{~min}$ at $60^{\circ} \mathrm{C}$ decreased by $1^{\circ} \mathrm{C}$ every cycle, $1 \mathrm{~min}$ at $72{ }^{\circ} \mathrm{C}$, followed by 27 thermal cycles of $94^{\circ} \mathrm{C}$ for $1 \mathrm{~min}, 1 \mathrm{~min}$ at $52^{\circ} \mathrm{C}$ decreased by $1^{\circ} \mathrm{C}$ every cycle, $1 \mathrm{~min}$ at $72{ }^{\circ} \mathrm{C}$, and final extension step at $72{ }^{\circ} \mathrm{C}$ for $10 \mathrm{~min}$ were set.

\subsection{DGGE analysis and sequencing of DGGE bands}

Denaturing gradient gel electrophoresis (DGGE) was performed with D-Code ${ }^{\mathrm{TM}}$ universal mutation detection system (BioRad Lab., USA). PCR product were loaded on to $8 \%(\mathrm{w} / \mathrm{v})$ polyacrylamide gels with a denaturing gradient of $40-55 \%$ (100\% denaturant according to $7 \mathrm{M}$ urea plus $40 \%$ formamide in $1 \times$ TAE buffer) and were run for $16 \mathrm{~h}$ at $80 \mathrm{~V}$ and at a constant temperature in $1 \times \mathrm{TAE}$ buffer (pH 7.4). After electrophoresis, the gels were stained with SYBE Safe TM (Invitrogen, UK), and then were put in a shaker at $150 \mathrm{rpm}$ for $10 \mathrm{~min}$, followed by excision bands from the gel with a pipette tip under UV illumination. The excised bands were directly placed in $1.5 \mathrm{ml}$ micro-centrifugation tubes containing $50 \mu \mathrm{l}$ ultrapure DNase/RNase-free sterile water and incubated at $4{ }^{\circ} \mathrm{C}$ for overnight to elute DNA. Ten microliters of the supernatants was used as template for the re-amplification (as described above). The resulting amplicons were again electrophoresed on a DGGE gel to verify the position of the original band. Subsequently, the amplicons were purified using the Gel/PCR DNA fragments extraction kit (Geneaid, Taiwan) and sequences (Mission Biotech. Co., Taiwan). All sequences were compared to those in the GeneBank database and Ribosomal database.

\subsection{Statistical analysis}

DGGE banding patterns were analyzed using Quantity One software (BioRad, USA). For cluster analysis, PCR-DGGE of one primer set was performed in duplicate. Calculation of the pair-wise

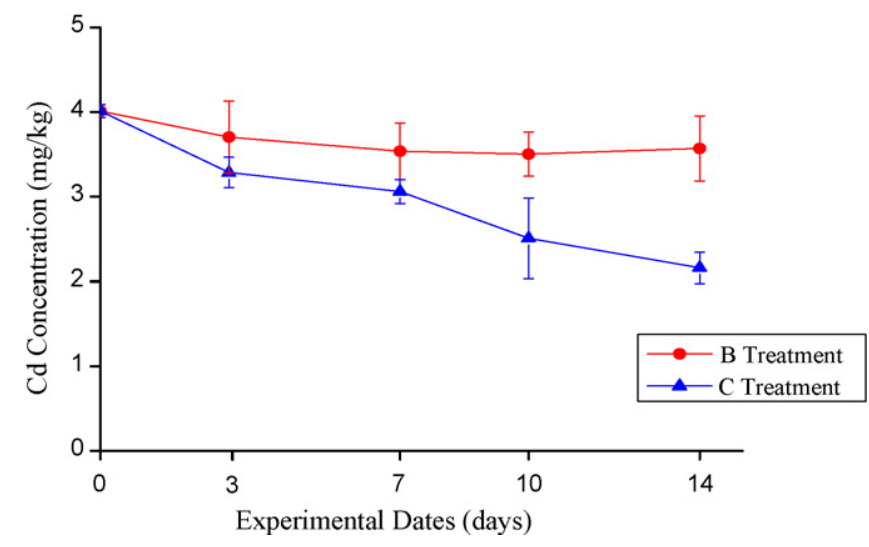

Fig. 1. The level of $\mathrm{Cd}(5 \mathrm{mg} / \mathrm{kg}$ dry weight of soil) in soil was decreased by the addition of ten earthworms into the soil (group C treatment), while group B treatment indicated that no earthworms were added into the this $\mathrm{Cd}$-contaminated soil. The values of percentage were calculated from the residual $\mathrm{Cd}$ concentrations divided by $5 \mathrm{mg} / \mathrm{kg}$ and then multiplied by 100 . Each value was derived form the average of three independent experiments. 


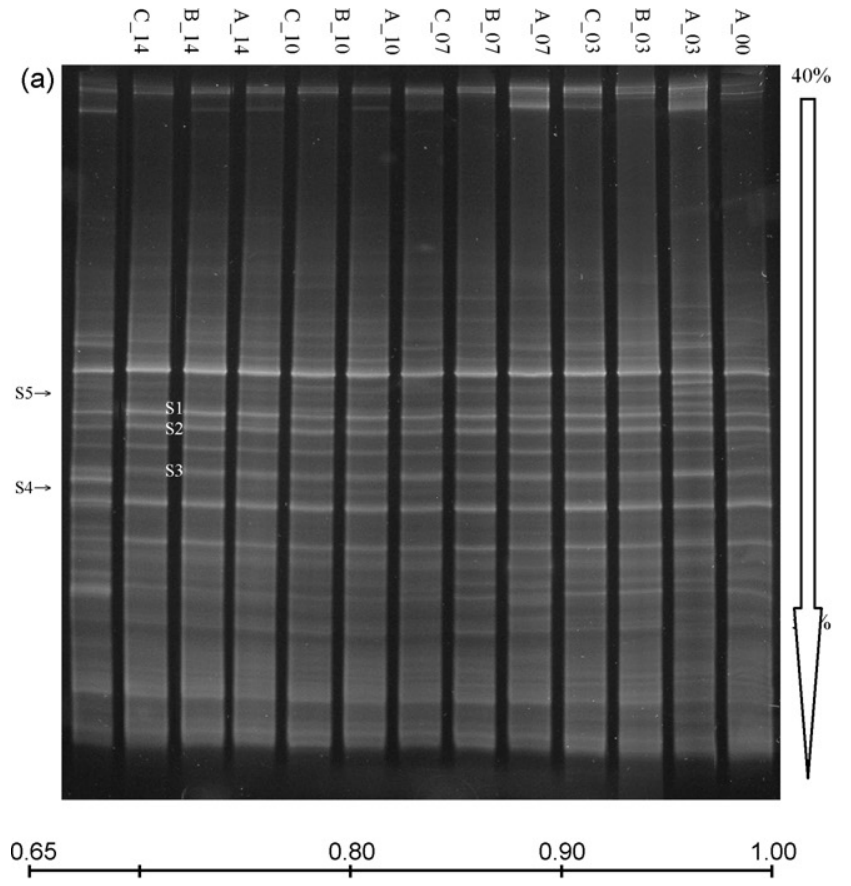

(b)

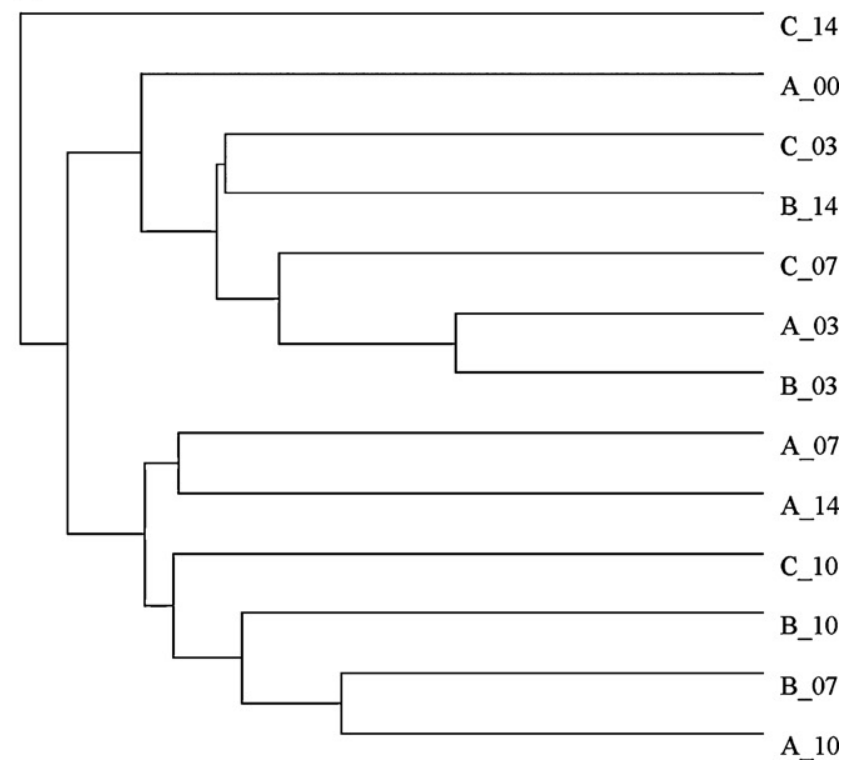

Fig. 2. (a) A bacterial fingerprints based on $16 \mathrm{~S}$ rDNA extracted from the noncontaminated soils with earthworms (A group), Cd-contamination soils (B group), and Cd-contaminated soil with earthworms (C group). Values near the side of each group indicate for incubation time. (b) Subsequently, this DGGE fingerprint was analyzed by the UPGMA method.

similarities was based on the Dice correlation coefficient. Dendrograms were created using the algorithm of unweighted pair-group method using arithmetic averages (UPGMA) [20].

Student $t$-test was used to compare the difference of the weight of earthworm with $\mathrm{Cd}$ and without $\mathrm{Cd}$ treatment. Analysis of variance (ANOVA) and Turkey's multiple range test $(p<0.05)$ were performed to compare the difference of $C d$ concentration in soil and earthworm in the tested three groups using SPSS software, version 10.0.7C. All of the experiments were performed in at least three replicates.
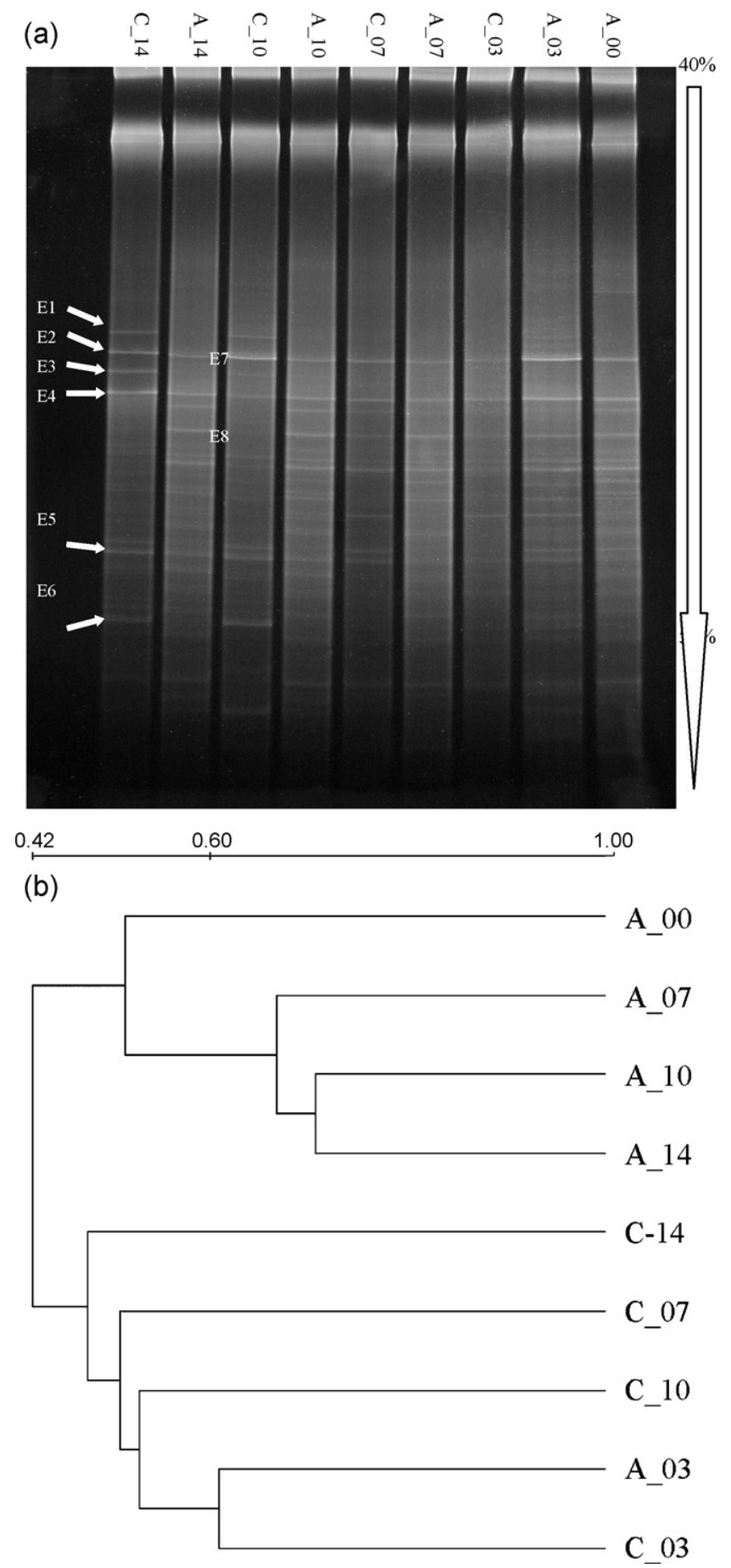

Fig. 3. (a) A bacterial fingerprints based on $16 \mathrm{~S}$ rDNA extracted from the guts of earthworms without $\mathrm{Cd}$ treatment (A group) and earthworms with Cd treatment (C group). Values near the side of each group indicate for incubation time. (b) Subsequently, this DGGE fingerprint was analyzed by the UPGMA method.

\section{Results}

\subsection{The effects of Cd on earthworm weight and survival}

To avoid the influence of the gut bacteria by ingested food, the earthworms were not fed during the 14-d incubation with $\mathrm{Cd}$. The weight of earthworms (group A) or (group C) was decreased to the same level after 14-d incubation (data not shown). After analysis of $t$-test, this result indicated that Cd did not affect earthworms weight $(p>0.05)$. For the survival analysis, the survival rates of 
earthworms derived from the ratio of the live earthworms to the death earthworms in both groups were over 97\% after 14-d incubation, suggesting that Cd level was not lethal to those earthworms' survival.

\subsection{Cd accumulation by earthworms}

During 14-d incubation, the Cd concentration in soil remained constant (i.e., $5 \mathrm{mg} / \mathrm{kg}$ ) in group B (without earthworm), while a decreased concentration of $\mathrm{Cd}$ was observed in soil belonging to group $C$ (with earthworm) (Fig. 1). To evaluate the potential of $\mathrm{Cd}$ removal by earthworm, the concentration of $\mathrm{Cd}$ in the earthworm was also determined. In the group $\mathrm{C}$ treatment (Fig. 1), results revealed that the levels of $\mathrm{Cd}$ in earthworm (the contents of Cd/dry weight of earthworms) or soil were below detection limit or $5.0 \pm 0.5 \mathrm{mg} / \mathrm{kg}, 3.45 \pm 0.44 \mathrm{mg} / \mathrm{kg}$ or $3.29 \pm 0.18 \mathrm{mg} / \mathrm{kg}, \quad 5.07 \pm 0.78 \mathrm{mg} / \mathrm{kg}$ or $3.06 \pm 0.14 \mathrm{mg} / \mathrm{kg}$, $7.35 \pm 0.55 \mathrm{mg} / \mathrm{kg}$ or $2.51 \pm 0.48 \mathrm{mg} / \mathrm{kg}$, and $11.3 \pm 0.60 \mathrm{mg} / \mathrm{kg}$ or $2.16 \pm 0.18 \mathrm{mg} / \mathrm{kg}$ at the sampling days $0,3,7,10$, and 14 , respectively. When the value of bioconcentration factor (BCF) derived from the ratio of $\mathrm{Cd}$ concentration in the earthworm/Cd concentration in soil is smaller than 1 , it shows that earthworms can only absorb but not accumulate heavy metals. On the other hand, it shows that earthworms can accumulate metals if $\mathrm{BCF}>1$. Our results revealed that the values of BCF were 1.05, 1.66, 2.93 and 5.23 at sampling day, $3,7,10$, or 14 , indicating that $\mathrm{Cd}$ can be accumulated in the earthworms. As shown in Fig. 1, the level of Cd ( $5 \mathrm{mg} / \mathrm{kg})$ remained constant in soil without earthworms (group B) but was decreased at days 10 and $14(p<0.001)$ after earthworms addition (group $\mathrm{C}$ ), which could highlight the fact that $\mathrm{Cd}$ can be removed by earthworms.

\subsection{Band identification}

Although a high number of bands appeared when performing PCR-DGGE analysis with universal bacterial primers, it was only possible to identify few bands by excising them from the DGGE. Weak and close bands were difficult to cut off the gel and could not be re-amplified or only produced multiple DNA sequences. After $10-d$ or $14-d$ incubation, the prominent bands of group $A$, group $C$ or differential bands in group $C$ as compared to group A, which was indicated in Figs. 2a and 3a, were excised. Subsequently, the excised bands were sequenced and then were compared to some database such as GeneBank. Results (Table 1) showed that these sequences are separately assigned to Alcaligenes sp. (S1), Uncultured Xanthomonadaceae bacterium (S2), Uncultured Rhodocyclaceae bacterium (S3), Nitrosomonas sp. Nm58 (S4), Verrucomicrobia bacterium (S5), Bacillus sp. NN106
(E1), Stenotrophomonas sp. D2 (E2), Actinobacterium (E3), Bacillus marinus (E4), Labrys, sp. CC-BB4 (E5), Bradyrhizobium japonicum (E6), and Stenotrophomonas sp. D2 (E7).

\subsection{Comparison of bacterial community in soil and the gut of earthworm among groups}

DGGE banding patterns were normalized and analyzed using Quantity One software (BioRad, USA). The similarities of these banding patterns were calculated based on the Dice correlation coefficient. Subsequently, the UPGMA method was used for cluster analysis. Cluster analysis of PCR-DGGE fingerprinting patterns of soil in groups A, B, and C during 14-d incubation was found in Fig. 2b, revealing that distinctive separations of the bacterial community in these soil cannot be detected. However, comparing the banding patterns of the bacterial community of the gut of earthworm with Cd treatment (group C) and without Cd treatment (group A), we found a clear separation of the bacterial community depending on Cd treatment although the fingerprinting patterns of group A at day 3 incubation showed less similarities than those of group $A$ at days $0,7,10$, and 14 (Fig. 3b), whereas group B was not included for this analysis due that this group contains only Cd-contaminated soil. This result suggested that the bacterial community of the gut was changed by Cd treatment.

\section{Discussion}

In this study, we analyzed the bacterial community in the gut of the $M$. posthuma, the common species found in soil of Taiwan, under the exposure of $\mathrm{Cd}$ by using a molecular fingerprinting methodDGGE. DGGE was an appropriate tool to simultaneously analyze samples from the soil with or without Cd treatment and the gut of M. posthuma on one gel and compare their banding patterns.

Our results demonstrated that $\mathrm{Cd}$ can be bio-accumulated by M. posthuma based on the value of the BCF. BCF was calculated as the ratio of the content of heavy metal in the earthworms to that in the soil. By using the BCF, we can confirm whether earthworms absorb or accumulate heavy metals [9]. Although it was reported that $\mathrm{Cd}$ can be accumulated by some species of earthworms such as Dendrobaena veneta [20], Enchytraeus buchholzi [21], Lumbricus rebellus [7], and Elsenia fetida [19], the effects of Cd accumulation in the bacterial community of the gut of earthworms are not known to date.

Cadmium has been reported to affect the microbial community of the contaminated soil as compared to the control set [22-25]. It is anticipated that the bacterial community in soil with anthropogenic chemical such as $\mathrm{Cd}$ was different from that without Cd. Furthermore, the microbial community of soil may also be

Table 1

Closest relatives of excised DGGE bands as revealed by BLAST N research in GeneBank database.

\begin{tabular}{|c|c|c|c|}
\hline DGGE $^{a}$ band & Closest relative & Accession number & Similarity $^{\mathrm{b}} \%$ \\
\hline S1 & Uncultured Alcaligenes sp. & EF173341 & 94 \\
\hline S2 & Uncultured Xanthomonadaceae bacterium & EF018313 & 97 \\
\hline S3 & Uncultured Rhodocyclaceae bacterium & EF018551 & 96 \\
\hline S4 & Nitrosomonas sp. Nm58 & AY123799 & 92 \\
\hline S5 & Uncultured Verrucomicrobia bacterium & AM690912 & 96 \\
\hline E1 & Bacillus sp. NN106 & AJ973278 & 93 \\
\hline E2 & Stenotrophomonas sp. D2 & DQ839619 & 99 \\
\hline E3 & Uncultured Actinobacterium & EF220604 & 97 \\
\hline E4 & Bacillus marinus & AJ237708 & 93 \\
\hline E5 & Labrys sp. CC-BB4 & DQ062742 & 98 \\
\hline E6 & Bradyrhizobium japonicum & DQ517954 & 99 \\
\hline E7 & Stenotrophomonas sp. D2 & DQ839619 & 99 \\
\hline E8 & Uncultured bacterium (unclassified) & DQ340200 & 93 \\
\hline
\end{tabular}

a The excised DGGE bands were indicated in Figs. 2a and 3a.

b The similarity of all sequences was obtained from comparison to those in the GeneBank database (http://blast.ncbi.nlm.nih.gov/Blast.cgi). 
profoundly affected by the presence of earthworm [13]. An increase in microbial numbers of in the gut of earthworms after the ingestion of soil containing a large portion of bacteria was reported [13], whereas heavy metal contamination decreased the diversity of bacterial community in the soil [9]. Although no distinctive clusters performed with UPGMA analysis for these soils were obtained, this analysis can be applied for analyzing the gut dependent on the presence of Cd (Fig. 3b). After the exposure to Cd in soil, the gut bacterial communities of the earthworms were changed as compared to that of earthworms in soil without Cd treatment based on the observations that a shift of some prominent bands and a decreased number of bands in DGGE profiles was found in the gut treated with Cd compared with that without $\mathrm{Cd}$ treatment (Fig. 3a). Thus, we concluded that bacteria communities in the gut were changed after the exposure of the earthworms to $\mathrm{Cd}$ in soil at a sub lethal concentration ( $5 \mathrm{mg} / \mathrm{kg}$ ) which did not affect the earthworms' viability.

Although DGGE has been widely used for the exploration of the microbial community qualitatively in soil, it still has limitation that its profiles represent only the most dominant phylotypes in the investigated samples [26]. Therefore, our banding patterns reflect only the abundant organisms, whereas less abundant representatives of the microbial community or microbes strongly attached to the gut wall resulting in the difficulty in the DNA extraction of these bacteria, which were hardly analyzed by DGGE, are not likely to be included in our analysis. The efficiency of DNA extraction from some sample such as soil often presents a major obstacle for subsequent DGGE analysis. Another limitation is that it is frequently not possible to obtain a pure DNA sequence from a band, as DGGE bands are overlapping or cannot be separated efficiently from each other during excision [27]. Moreover, the UV light used to make bands visible when cutting them off the DGGE may destroy the DNA and lead to sequence variation artifacts [28]. Thus, to ensure our DGGE profile reliable and avoid the occurrence of these limitations when performing the DGGE analysis, we added some known bacterial species such as the representative gram-positive (e.x. Bacillus sp.) and gram-negative species (e.x. Pseudomonas sp.), which were common seen in the environment, to the analyzed soil or gut as the internal standards, and then detect their presence from the excised bands in the DGGE profiles. Our results revealed that DGGE profiles were highly reproducible in a triplicate-independent manner.

Based on the criteria that only sequences displaying an identity of more than $97 \%$ were considered to represent the same species [29], Bradyrhizobium japonicum, Labrys sp. CC-BB 4, and Stenotrophomonas sp. D2 from the gut of the earthworms in soil contaminated with and without $\mathrm{Cd}$ were identified in Table 1 . One species of Stenotrophomonas sp., Stenotrophomonas maltophilia, has the ability to remove $2 \mathrm{mM}$ Cd by increasing the level of cysteine to form CdS-cluster formation [30]. Stenotrophomonas sp. CD02 can remove $80 \%$ of high concentrations of cadmium ion (up to $4 \mathrm{mM}$ ) [31]. Bradyrhizobium japonicum is a soil bacterium involved in symbiotic nitrogen fixation with Glycine max, the common soybean, and its strain USDA 122 but not USDA 123 is resistant to Cd toxicity [32]. The ability of Labrys sp. to detoxify or resist Cd toxicity is still not known. Since some of these identified bacteria, particularly in Stenotrophomonas sp. D2 and Bradyrhizobium japonicum, were found in both the guts of the earthworms and their dwelling soil, the presence of these bacteria in the gut could be indigenous or mainly from the ingestion of soil by earthworms. Thus, whether Stenotrophomonas sp. D2 and Bradyrhizobium japonicum were related with the ability of $M$. posthuma to bio-accumulate $\mathrm{Cd}$ still needs to be investigated.

\section{Conclusion}

The results of this study demonstrated that DGGE was a useful molecular technique for analyzing the bacterial community in the gut of $M$. posthuma. Excising bands from the DGGE did not allow for the identification of all bands of interest; however, this technique made it possible to identify some of the most abundant bacteria in the earthworm gut. Additionally, the setting up of a clone library from the gut samples will be necessary to fully elucidate the bacterial community in gut, offering a more detailed overview about the gut microbiota of $M$. posthuma. Collectively, we first demonstrated that the bacterial communities in the gut but not in their surrounding soil are changed by $\mathrm{Cd}$. Alterations in the composition of microbial communities have often been proposed to be a sensitive indicator anthropogenic effects on soil ecology [33].

\section{References}

[1] M. Udovic, D. Lestan, The effect of earthworm on the fraction and bioavailability of heavy metals before and after soil remediation, Environ. Pollut. 148 (2007) 663-668.

[2] G. Yongcan, W. Zhenzhong, Z. Youmei, M. Xiaoyang, Bioconcentration effects of heavy metal pollution in soil on the mucosa epithelia cell ultrastructure injuring of the earthworm's gastrointestinal tract, Bull. Environ. Contam. Toxicol. 60 (1998) 280-284

[3] J.E. Morgan, A.J. Morgan, Seasonal changes in the tissue-metal (Cd, $\mathrm{Zn}$ and $\mathrm{Pb}$ ) concentrations in two ecophysiologically dissimilar earthworm species: pollution-monitoring implications, Environ. Pollut. 82 (1993) 1-7.

[4] C.J. Langdon, T.G. Piearce, S. Black, K.T. Sempke, Resistance to arsenic-toxicity in a population of the earthworm Lumbricus rubellus, Soil Biol. Biochem. 31 (1999) 1963-1967.

[5] C.J. Langdon, T.G. Piearce, A.A. Meharg, K.T. Semple, Survival and behavior of the earthworm Lumbricus rubellus and Dendrolus rubidus from arsenatecontaminated and one-contaminated sites, Soil Biol. Biochem. 33 (2001) 1239-1244.

[6] F. Marino, S.R. Sturzenbaum, P. Kille, A.J. Morgan, $\mathrm{Cu}-\mathrm{Cd}$ interactions in earthworms maintained in a laboratory microcosm: the examination of a putative copper paradox, Comp. Biochem. Physiol. C Pharmacol. Toxicol. Endocrinol. 120 (1998) 217-223

[7] T.T. Ngu, S.R. Sturzenbaum, M.J. Stillman, Cadmium binding studies to the earthworm Lumbricus rubellus metallothionein by electrospray mass spectrometry and circular dichroism spectroscopy, Biochem. Biophys. Res. Commun. 351 (2006) 229-233

[8] M.P. Ireland, Heavy metal uptake and tissue distribution in earthworms, in: J.E. Satchell (Ed.), Earthworm Ecology, Chapman and Hall, London, 1983, pp. 247-265.

[9] Z. Li, J. Xu, C. Tang, J. Wu, A. Muhammad, H. Wang, Application of 16S rDNA-PCR amplification and DGGE fingerprinting for detection of shift in microbial community diversity in $\mathrm{Cu}-, \mathrm{Zn-}$, and Cd-contaminated paddy soils, Chemosphere 62 (2006) 1374-1380.

[10] A.J. Morgan, C. Winters, A. Yarwood, Speed-mapping of arsenic distribution in the tissues of earthworms inhabiting arsenic soil, Cell Biol. Int. 18 (1994) 911-914.

[11] F.M. Romijn, R. Luttik, J. Canton, Presentation of a general algorithm to include effect assessment on secondary poisoning in the derivation of environmental quality criteria. 2. Terrestrial food chains, Ecotoxicol. Environ. Saf. 26 (1994) 61-83.

[12] D.J. Spurgeon, S.P. Hopkin, Risk assessment of the threat of secondary poisoning by metals of predators of earthworms in the vicinity of a primary smelting works, Sci. Total Environ. 187 (1996) (1996) 167-183.

[13] M.A. Furlong, D.R. Singleton, D.C. Coleman, W.B. Whitman, Molecular and culture-based analyses of prokaryotic communities from an agricultural soil and the burrows and casts of the earthworm Lumbricus rubellus, Appl. Environ. Microbiol. 68 (2002) 1265-1279.

[14] B.A. Kanpp, J. Seeber, S.M. Podmirseg, E. Meyer, H. Insam, Application of denaturing gradient gel electrophoresis for analyzing the gut microflora of Lumbricus rebellus Hoffmeister under different feeding conditions, Bull. Entomol. Res. 98 (2008) 271-279.

[15] T. Vanhoutte, G. Huys, E. De Brandt, J. Swings, Temporal stability analysis of the microbiota in human faces by denaturing gradient gel electrophoresis using universal and group-specific 16S rRNA gene primers, FEMS Microbiol. Ecol. 48 (2004) 437-446.

[16] J.M. Simpson, V.J. McCracken, B.A. White, H.R. Gaskins, R.L. Mackie, Application of denaturant gradient gel electrophoresis for the analysis of the porcine gastrointestinal microbiota, J. Microbiol. Methods 36 (1999) 167-179.

[17] A.F. Reeson, T. Jankovic, M.L. Kasper, S. Rogers, A.D. Austin, Application of 16S rDNA-DGGE to examine the microbial ecology associated with a social wasp Vespula germanica, Insect Mol. Biol. 12 (2003) 85-91.

[18] H. Tanaka, H. Aoyagi, S. Shina, Y. Dodo, T. Yoshimura, R. Nakamura, H. Uchiyama, Influence of the diet components on the symbiotic microorganisms community in hindgut of Coptoterms formosanus shiraki, Appl. Microbiol. Biotechnol. 71 (2006) 907-917.

[19] S. Demuynck, F. Grumiaux, V. Mottier, D. Schikorski, S. Lemière, A. Leprêtre, $\mathrm{Cd} / \mathrm{Zn}$ exposure interactions on metallothionein response in Eisenia fetida (Annelida, Oligochaeta), Comp. Biochem. Physiol. C Toxicol. Pharmacol. 145 (2007) 658-668. 
[20] A.M. Ibekwe, S.K. Papiernik, J. Gan, S.R. Yates, C.H. Yang, D.E. Crowley, Impact of fumigants on soil microbial communities, Appl. Environ. Microbiol. 67 (2001) 3254-3257.

[21] J.Willuhn, H.P.Schmitt-Wrede, A. Otto, F. Wunderlich, Cadmium-detoxification in the earthworm Enchytraeus: specific expression of a putative aldehyde dehydrogenase, Biochem. Biophys. Res. Commun. 226 (1996) 128-134.

[22] S. Khan, Q. Cao, A.-L. Hesham, Y. Xia, J.Z. He, Soil enzymatic activities and microbial community structures with different application rates of $\mathrm{Cd}$ and $\mathrm{Pb}, \mathrm{J}$. Environ. Sci. (China) 19 (2007) 834-840.

[23] J.L. Shentu, Z.L. He, X.E. Yang, T.Q. Li, Microbial activity and community diversity in a variable charge soil as affected by cadmium exposure levels and time, J. Zhejiang Univ. Sci. B9 (2008) 250-260.

[24] X. Liu, C. Hu, S. Zhang, Effects of earthworm activity on fertility and heavy metal bioavailability in sewage sludge, Environ. Int. 31 (2005) 874-879.

[25] A. Muhammad, H.Z. Wang, J.J. Wu, J.M. Xu, D.F. Xu, Changes in enzymes activity, substrate utilization pattern and diversity of soil microbial communities under cadmium pollution, J. Environ. Sci. (China) 17 (2005) 802-807.

[26] G. Muyzer, E.C. de Waal, A.G. Uitterlinden, Profiling of complex microbial populations by denaturing gradient gel electrophoresis analysis of polymerase chain reaction amplified genes for 16S rRNA, Appl. Environ. Microbiol. 59 (1993) 695-700.
[27] J.M. Gonzalez, A. Ortiz-Martinez, M.A. Gonzalez-Delvalle, L. Laiz, C. SaizJimenez, An efficient strategy for screening large cloned libraries of amplified $16 \mathrm{~S}$ rDNA sequences from complex environmental communities, J. Microbiol. Methods 55 (2003) 459-463.

[28] C. Schabereiter-Gurtner, G. Pinar, W. Lubitz, S. Rolleke, An advanced molecular strategy to identify bacterial communities on art objects, J. Microbiol. Methods 45 (2001) 77-87.

[29] V. Kisand, R. Cuadros, J. Wikner, Phylogeny of culturable estuarine bacteria catabolizing reverine organic matter in the northern Baltic sea, Appl. Environ. Microbiol. 68 (2002) 379-388.

[30] D. Pages, J. Rose, S. Conrod, S. Cuine, P. Carrier, T. Heulin, W. Achouak, Heavy metal tolerance in Stenotrophomonas maltophilia, PLoS ONE 3 (2008) e1539.

[31] C.C. Chien, C.W. Hung, C.T. Han, Removal of cadmium ions during stationary growth phase by an extremely cadmium-resistant strain of Stenotrophomonas sp., Environ. Toxicol. Chem. 26 (2007) 664-668.

[32] B.K. Kinkle, J.S. Angles, H.H. Keyser, Long-term of metal rich sewage sludge application on soil populations of Bradyhizobium japonicum, Appl. Environ. Microbiol. 53 (1987) 315-319.

[33] G. Renella, M. Mench, L. Landi, P. Nannipieri, Microbial activity and hydrolase synthesis in long-term Cd-contaminated soils, Soil Biol. Biochem. 37 (2005) 133-139. 